\title{
The evaluation of the tourist capacity in the Roztoczański National Park
}

\author{
Emilia Janeczko $\bowtie$, Magdalena Gucma \\ Warsaw University of Life Sciences, Faculty of Forestry, Nowoursynowska 159, 02-776 Warsaw, Poland, \\ phone: +48 22 5938134, e-mail: janeczko.emilia@gmail.com
}

\begin{abstract}
The article presents the methodological assumptions and the results of the assessment of the capacities of Roztoczański Park Narodowy (RPN). Evaluation was a result of the capacity of hiking trails and educational paths and capacity of the surface of recreational facilities located in the RPN. Measure of capacity assessment of recreational trails was their length, average speed of movement the user, the nature of tourism (individual tourists and groups) and living life paths. Results of the research can serve as a basis for identifying principles of tourism and recreational use of RPN.
\end{abstract}

\section{KeY WORDS}

tourism, tourist pressure, tourist management, national park

\section{INTRODUCTION}

Currently in Europe the number of visitors to areas of natural value and protection continues to increase. Areas are particularly susceptible to degradation and therefore require prudent management of the environment. According to Coccossis et al. (2002), in 1994 valuable natural areas constituted the intentional distillation for about $40 \%$ to $60 \%$ of the tourists. Tourism in protected natural areas is now $7 \%$ of all international tourist expenditure. World Tourism Organization (WTO) estimates that $20 \%$ of the 600 million international trips in 1997 was associated with the development of ecotourism (Coccossis et al. 2002). Number of visitors to the Polish national parks is currently around 11 million per year (http://www.mos.gov.pl/artykul/2236 parki_narodowe/311_parki_narodowe.html). National
Parks'aprimary function is protection, but among the tasks that perform social tasks are also associated with the provision of land for tourism purposes. Parks contribute not only to meet the basic needs of human contact with nature, but they are also a form of gaining knowledge of nature and sightseeing. Various forms of human activity, especially those of an economic nature, and such is classified as a tourism, create, or may in the future pose a threat to set out the natural environment and cultural heritage. Therefore, the protection of nature, landscape and cultural values requires certain adjustments, identify ways to eliminate or reduce existing and potential internal and external threats and their consequences. The basic document which includes detailed rules for the use of the national park and landscape reservation formula for a period of 20 years is the Nature Conservation Act (OJ 2004, No. 92, item 880) 
- a protection plan. Restrictions on land use in national parks are restrictive to the extent that ensures the effective protection of the whole nature and landscape values. A detailed list of activities related to the creation of a project management plan for national parks is defined in the Regulation of the Minister of Environment of 12 May 2005 (OJ No 94/2005, item. 794). The analysis of a series of guidelines for the creation of a national park protection plan is also given in the regulation above. Regulation leads to the conclusion that, at present in the context of the development of tourism and recreation, particular attention is paid to the trails, ignoring other elements of tourism development (e.g. accommodation facilities) and recreational space (e.g. parking and stopping place, viewpoints, clearing recreation spots). In these regulations there is no apparent need for a detailed inventory of tourist facilities and the elements of recreational land use. As part of conservation plans there is no need to present indicators on the size, seasonality accommodation and catering. Authors'uprotection plans are also not required to determine the capacity development of tourism and recreation, much less take account of tourism resources located outside the boundaries of the area covered by the plan, in its close proximity. Meanwhile, it seems that just indicators of tourist capacity (tourism carrying capacity TCC), understood as the maximum number of people who visit the area, tourist destination at the same time without initiating the degrading processes in the environment (physical, socio-economic and cultural) and the deterioration of safeguarded recreation (Coccossis et al. 2002; Jędrzejczyk 1995; Warszyńska and Jackowski 1978) may be a particular argument in favour of the development, or limit the functionality of tourists space. The following work is to analyse the possibility of the development of tourism in the National Park Roztoczański as far as the tourist capacity is concerned.

Roztoczański National Park is not only a particular area because of the unique qualities of the natural environment and also the terrain perceived as very attractive because of the possibility of achieving the objectives of tourism and recreation. In Roztoczański National Park there are no constant, systematic studies and observations on tourism. The data provided by the Park show that in 2011 the number of tourists in the Park was over 26,000 people in 2012, more than 29,000 tourists. According to the decree 7/2014 Director Roztoczański PN penetration site in the Park can be done within a year, in daylight, from sunrise to sunset. Tourist groups sightseeing Park cannot exceed 60 people. Walking paths on Bukowa Mountain in a group of more than 10 people are allowed only under the supervision of clerk authorized by the Director of RPN or other person authorized by the Director of the Park.

The park was established in 1974. Currently an area of 8483 acres, including forests occupy 8102 ha (95.5\%). Strict protection covered 1029 ha (12.1\%). Park area includes most precious natural piece of mites, which is located at the junction of four physiographic provinces: Central Mites, Mites West, vale Zamoyski and Plain Biłgorajska in the central-eastern part of the country, in the province of Lublin. The terrain of the Park is a place suitable for active tourism and sightseeing. For users who cover the area of the Park on foot, there are nine cognitive paths with a total length of $18 \mathrm{~km}$. Across the Park area also runs five transit walking routes whose total length, within the RPN is $34 \mathrm{~km}$. Cycling in Park develops on four bicycle trails with a total length of $17 \mathrm{~km}$. Outside designated nature trails, hiking and cycling routes, a very popular place for recreation in the park are ponds "Echo", created in the years 1929-1934 on the site of wetlands located in at the Świerszcz river. Increased influx of tourists to the area of Roztoczański $\mathrm{PN}$, especially during the summer promotes the development of the village adjacent to the Park. The Park does not have its own database of accommodation and catering.

\section{MATERIAL AND MEthOdS}

The analysis methods used to evaluate tourism capacity (including Sołowiej et al. 1993; Sewerniak 1980; Jagusiewicz 1981; Płocka 1996; Czochański 1997) was the basis for determining the factors of conditions chipping tourist capacity. It was also an attempt to determine the advantages and disadvantages of use of methodological solutions. As a result of this analysis it was assumed that the capacity of RPN is the sum of the daily capacity of swimming at Echo Ponds and at the fold of Polish Horses breeding, hiking, biking and educational paths.

While assessing the land use capacity of spatial recreational facilities, that is, swimming, clearing the recreation spots, the surface and norms, recommenda- 


\section{DE GRUYTER

tions for projects of this type were taken into account. While evaluating the bathing capacity BaranowskaJenota (1996) normative was considered referring to the size of the integrated bathing beaches, which was set as 1 person $/ 10 \mathrm{~m}^{2}$ beach. However, recreational spots adopted a normative determined by Łonkiewicz and Głuch (1991) as 1 person/100 $\mathrm{m}^{2}$.

The various factors determining the capacity of routes included, in the evaluation capacity of recreational trails, the following parameters: length of the routes, the average speed of movement of tourists, nature tourism (individual tourists, groups of interest) and daily time use trails. Details of the length of routes were derived from available maps and tourist guides. Speed of the users of routes defined as: $4 \mathrm{~km} / \mathrm{h}$ on hiking trails on foot, $12 \mathrm{~km} / \mathrm{h}$ on tourist routes cycling, $2 \mathrm{~km} / \mathrm{h}$ on educational paths (speed this allows free access to the explanations on the route, stopping to listen to the guide and the observation of nature and cultural elements). Based on surveys conducted in the Park 2013 (Gucma 2013) - among others, the size and nature of tourism has been established that the average size of the group of tourists on hiking and cycling routes is 20 people, while in relation to the educational paths -10 people. Field observations also allowed to determine the average lifetime of recreational trails. For hiking trails hiking is a 540 minutes during the day, cycling is $\mathbf{5 7 0}$ minutes and the educational paths is 420 minutes.

To assess the capacity of routes RPN has been adapted with some modifications the methods of Sewerniak (1980) and of Płocka (1996). Modifications necessary due to the nature of the area concerned mainly RPN rotation factor (i.e., shortened the average veil of used routes). In addition, the calculation of the routes included the fact that the routes used by both individual travellers and groups. The first stage capacity assessment was to determine the recreational trails rotation factor for the standard section with a length of $1 \mathrm{~km}$. It was assumed by Sewerniak (1980) that:

$$
N_{w}=\frac{T_{u}-T_{p}}{T_{p}}, \quad T_{p}=C_{p}+C_{o}
$$

where:

$N_{w}$ - rotation ratio,

$T_{u}$ - time all-day use,

$T_{p}$ - time travelling episode reference,
$C_{p}$ - penetration time reference section,

$C_{o}$ - time breaks in the penetration of example section.

Determination of the factor of a rotation with the adoption of the assumption that the minimum distance for comfort penetration res axis $200 \mathrm{~m}$ for tourists individual and 1,000 $\mathrm{m}$ for tourist group (Styperek 2002) as the basis for determining the capacity of standard distance (Pw). Capacity reference section, with the use only by individual travellers (IPR) is 5 people $(1000 \mathrm{~m}$ : $200 \mathrm{~m} \times 1$ person $=5$ people). In turn, the use by both individual tourists and tourist groups, this exclusive capacity $(\mathrm{Pwg})$ is 2 to 5 people $(1000 \mathrm{~m}: 200 \mathrm{~m} \times 11$ person $=5$ people $1000 \mathrm{~m}$ : $1000 \mathrm{~m} \times 020$ person $=20$ persons). The throughput reference segment is calculated by the formula:

$$
Q_{w}=P_{w} \times N_{w}
$$

where:

$Q_{w}$ - bandwidth episode utility example models,

$P_{w}$ - volume reference section,

$N_{w}$ - rotation ratio.

The total capacity of the tourist trail was expressed as the product of bandwidth and length of the reference section of the trail.

\section{Results}

On the basis of methodological assumptions and data size of the object surface area of recreational equipment ceased well, that the capacity of swimming at Ponds Echo, accompanied by a beach with an area of 0.56 ha is 560 people per day. In turn, the recreation spot in Florianka, with an area of 0.15 ha can simultaneously present a total of 15 people, taking into account the time of opening of the facility ( ten-hours a day) gives 150 people/day.

Given the assumptions and methodology for the determination of capacity on routes and recreational places, it is established that the ratio of the rotation for pedestrian hiking trails (with $\mathrm{Cp}=15 \mathrm{~min}$ and $\mathrm{Co}=$ $10 \mathrm{~min}$ ) is 21 hiking trails for biking and this increased to 70 (with $\mathrm{Cp}=5 \mathrm{~min}$ and $\mathrm{Co}=3$ minutes). However, for educational paths rotation factor value was 10 (with $\mathrm{Cp}=30 \mathrm{~min}$, and $\mathrm{Co}=10$ minutes). Taking into ac- 
count that regardless of the nature trail capacity gauge reference section $(\mathrm{Pw})$ is 5 (for use only by the individual travellers) and 25 (individual tourists and tourist groups) bandwidth of standard tourist trail segment was walking Qwi 105 people/day and Qwg - 525 people/day. In turn, the bandwidth of standard section of track cycling set at: Qwi $=350$ persons/day and Qwg $=$ 1750 people/day. While the throughput of an educational path section was: $\mathrm{Qwi}=50$ persons/day and $\mathrm{QWG}=$ 150 people/day.

Capacity of all hiking trails running through the park with a total length of $34 \mathrm{~km}$ is, therefore, taking into account only individual travellers (Qi): $\mathrm{Qi}=3570$ people/day, while taking into account both individual travellers and group amounted (Qg) to 17,850 persons/day.

Bandwidth hiking cycle, the length of which a total RPN is within $17 \mathrm{~km}$ calculated as: $\mathrm{Qi}=5950$ people/ day and $\mathrm{Qg}=29,750$ persons/day. Detailed information on hiking the bandwidth of each cycle is presented in table 1 .

Table 1. Bandwidth hiking cycling Roztoczański National Park

\begin{tabular}{|c|c|c|c|}
\hline \multirow[b]{2}{*}{ Name of the trail } & \multirow{2}{*}{$\begin{array}{l}\text { Length } \\
\text { of the } \\
\text { route }[\mathrm{km}]\end{array}$} & \multicolumn{2}{|c|}{ Throughput } \\
\hline & & $\begin{array}{c}\mathrm{Qi} \\
\text { [pers./day] }\end{array}$ & $\begin{array}{c}\mathrm{Qg} \\
\text { [pers./day] }\end{array}$ \\
\hline $\begin{array}{l}\text { Zoo-Florianka- } \\
\text { Górecko Stare }\end{array}$ & 13 & 4550 & 22,750 \\
\hline $\begin{array}{l}\text { Central Cycle Route } \\
\text { in Roztocze }\end{array}$ & 1.5 & 525 & 2625 \\
\hline $\begin{array}{l}\text { Polak Hill } \\
\text { "Borderland Regions" }\end{array}$ & 1 & 350 & 1750 \\
\hline $\begin{array}{l}\text { Bike Route } \\
\text { Józefowska Land }\end{array}$ & 1.5 & 525 & 2625 \\
\hline Total & 17 & 5950 & 29,750 \\
\hline
\end{tabular}

In turn, the total capacity of educational paths within the Park was established on Qi $=885$ people/day and $\mathrm{Qg}=2655$ people/day. Detailed information on the individual educational paths is presented in table 2 .

Throughput total of all hiking, mountain biking and educational paths running through the Park is 10,405 persons/day (including an exclusive individual travellers) and 50,255 persons/day, taking into account the individuals and groups.

The total capacity of the site of Roztoczański National Park which is the sum of the daily capacity of the recreation resort in Florianka, swimming ponds and capacity on routes Echo tourism and recreation is therefore 11,115 persons/day for tourists and 50,965 people/ day, after taking into account both individual travellers and groups.

Table 2. Bandwidth educational paths in Roztoczański National Park

\begin{tabular}{|c|c|c|c|}
\hline \multirow[b]{2}{*}{ Route Name } & \multirow{2}{*}{$\begin{array}{l}\text { Length of } \\
\text { the route } \\
{[\mathrm{km}]}\end{array}$} & \multicolumn{2}{|c|}{ Throughput } \\
\hline & & $\begin{array}{c}\mathrm{Qi} \\
\text { [pers./day] }\end{array}$ & $\begin{array}{c}\mathrm{Qg} \\
\text { [pers./day] }\end{array}$ \\
\hline $\begin{array}{l}\text { After the dune into the } \\
\text { joints Echo }\end{array}$ & 1.7 & 85 & 255 \\
\hline $\begin{array}{l}\text { Alexandra } \\
\text { Wachniewska Avenue }\end{array}$ & 0.7 & 35 & 105 \\
\hline Echo Ponds & 1.2 & 60 & 180 \\
\hline On Bukowa Mountain & 2.6 & 130 & 390 \\
\hline $\begin{array}{l}\text { Dendrological Path in } \\
\text { Florianka }\end{array}$ & 1.0 & 50 & 150 \\
\hline $\begin{array}{l}\text { Landscape path in } \\
\text { Florianka }\end{array}$ & 1.2 & 60 & 180 \\
\hline $\begin{array}{l}\text { Historical path to } \\
\text { Wojda }\end{array}$ & 4.0 & 200 & 600 \\
\hline $\begin{array}{l}\text { Historical gallery path } \\
\text { at Pole Hill }\end{array}$ & 2.1 & 105 & 315 \\
\hline $\begin{array}{l}\text { Path on Mount } \\
\text { Piaseczna }\end{array}$ & 3.2 & 160 & 480 \\
\hline Total & 17.7 & 885 & 2655 \\
\hline
\end{tabular}

\section{Discussion AND CONCLUSIONS}

Despite the improvement of various research methods to adapt the issue of land use recreational area for current and future needs of users is still not clearly resolved. The use of indicators tourist capacity, or as an interpretation of the assumptions recreation area development concept is still debatable. Number is a group of researchers, which include, for example, Buckley (1999), Stanley (1984) subject criticism of determining the legitimacy of tourist capacity. Among the arguments negating any assessment tourist capacity is the lack or expressive restriction on the practical application of any measures of tourist capacity. In a world where demand is shaped supply is very hard to enforce, there is a limit on environmentally valuable areas, characterized by a high protective regime. Number of tourists entering the Na- 


\section{DE GRUYTER

tional Park and the introduction of limits is difficult to implement and requires substantial financial resources and require the introduction of specific technical solutions (e.g. barriers, gates, security gates, etc.). Currently in Poland there are no legal requirement for the determination of capacity development of tourist-recreational national parks, landscape and nature reserves, which in practice hampers the implementation of the principles of sustainable development of tourism and recreation in these areas. Lacks in the arguments for the necessity of tourism development, which de facto means maintaining the status quo or even greater restrictions in relation to the current tourist-recreational use of national parks (Janeczko et al. 2014). It appears that the determination of the scope of necessary exclusions and limitations conflicting functions the overriding features a park with an indication of allowable spatial and programmatic needs absolutely indicate the permissible capacity of tourist and recreational facilities.

Capacity site surface facilities, as well as the capacity of linear tourist and recreational land use shall require the acceptance of others, resulting from the specific circumstances of location, methodological assumptions. For example, the bandwidth hiking water routes requires consideration of such output data and parameters such as the width, curvings, its obstructions, speed vessels. Owsiak (1991) notes that the capacity of the rivers will differ significantly depending on walk distance (top, middle, bottom) and is inversely proportional to the scale of the difficulties of their movements.

Michalski et al. (1979), in turn, suggests the need for different rules for the assessment of bandwidth mountain trails. This is due to the fact that in the lowlands, in contrast to the mountainous areas there are no trails serving as access trails (presence of walking trails). Besides, the path is a lowland, in comparison with mountain routes generally have to deal with lower traffic flow meters. In turn, the mountain usually width and hence patency of strings is much smaller. Based on these two examples (water trails, mountain trails), it is concluded that the optimal, appropriate management of tourism and recreation area, in particular national park requires choosing the method of evaluation capacity, taking into account the variability of environmental conditions. The use of a single, universal test method in this context is inappropriate and even from the point of view of nature conservation harmful.
Another important aspect of constructing the conceptual basis for the assessment of the capacity of tourism and recreation area is the issue of uneven during the year using various tourist and recreational facilities, as well as the specifics of tourism. Roztoczański is the example of the National Park, it is clear that while hiking on the trail of tourist increases from May to October, swimming in the Echo Ponds in the summer months. Taking into account the specific characteristics of tourism, it can be noted that the tourism group, dominated by school trips take place in RPN mainly in May and September. During July and August prevail all individual tourists. It means that the proper management of the environment requires the determination of capacity of tourism and recreation as well as detailed monitoring of tourism, including records of inputs turns in the national park.

In light of the studies and the results obtained gives rise to the following conclusions:

- the method is applied to the areas with small height differences of the site with its potential use in mountain areas, or upland and requires a different choice of parameters to assess the capacity/throughput

- methodological assumptions allow us to establish limit values for tourist traffic, and hence the detailed rules for the use of tourist-recreational protected areas

- there is a need for a research aimed to compare the results obtained from the measurement of frequency with the results in hands of users of protected areas.

\section{References}

Baranowska-Janota M. 1996. Tourist absorption of mountain ranges province in Krosno including the protected areas. In: Methodology of tourist capacity of mountain ranges including the regional capital of Rzeszów's protected areas. The program will be implemented by order of the Governor of Krosno.

Buckley R. 1999. An ecological perspective on carrying capacity. Annals of Tourism Research, 10 (3), 705-708.

Coccossis H., Mexa A., Collovini A. 2002. Defining, measuring and evaluating carrying capacity in European tourism destinations. B4-3040/2000/294577/ MAR/D2, University of the Aegean, Athens. 
Czochański J. 1997. Basic problems of sharing the TDI for hiking and environmental risk and bandwidth use of tourist trails. In: TPN Protection Plan. Sampling sharing for science, education and tourism.

Decree No. 7/2014 Director Roztoczański National Park in Zwierzyniec of 25 February 2014 on the principles of access to public Roztoczański National Park.

Gucma M. 2013. Social preferences for the cycling routes in the RPN and its buffer zone. Engineering work under the direction of Dr. E. Janeczko. Warsaw University of Life Sciences - SGGW, Warsaw.

Jagusiewicz A. 1981. Tourist capacity Bieszczady PN. Institute of Tourism, Warsaw.

Janeczko E., Woźnicka M., Janeczko K. 2014. Tourism and recreation in protection plans of Polish national parks on the example of the Wolin National Park. In: Public recreation and landscape protection-hand in hand? MENDELU, Brno, 308-312.

Jędrzejczyk J. 1995. Environmental conditions and functions of tourism. Wydawnictwo Śląsk, Katowice.

Łonkiewicz B., Głuch G. 1991. Guidelines for recreational management of forests. IBL, Warsaw.

Michalski J., Chudziakiewicz M.Z. 1979. Calculation capacity hiking dynamic programming methods. PWE, Warsaw.

Owsiak J. 1991. The absorption capacity and the capacity of the site area and their methods to take into account in planning. In: Tourism as a factor in social and economic development. The Central Year- book of Fundamental Research Program. Institute of Tourism, Warsaw.

Płocka J. 1996. Selected aspects of tourism development. Centre for Continuing Education, Toruń.

Sewerniak J. 1980. Methods for determining hiking in the coastal zone in terms of their capacity and bandwidth. In: Geographical basis of the tourist use of the coastal zone. Institute of Tourism, Warsaw.

Sołowiej D., Brzóska J., Krawczyk P. 1993. The natural absorbency of Słowiński National Park - recreation in the light of the natural values of the area. In: Landscape ecology studies Recreational Territorial Systems. Publisher of the National Research Institute of Local Government, Poznań, 107-115.

Stanley G.H. 1984. Carrying capacity in recreational setting: evolution, appraisal and application. Leisure Science, 6 (4), 453-473.

Styperek J. 2002. Linearne systemy penetracji rekreacyjnej. Linear systems of recreational penetration. Bogucki Wydawnictwo Naukowe, Poznań.

The Minister of Environment of 12 May 2005 on detailed rules for drawing up a plan for the protection of the national park, nature reserve and nature park, make changes to the plan and conservation, and wildlife components. OJ 94/2005, item 794.

The Nature Conservation Act of 16 April 2004. OJ 92/2004, item 880 with later changes.

Warszyńska J., Jackowski A. 1978. Fundamentals of tourism geography. PWN, Warsaw.

http://www.mos.gov.pl/artykul/2236_parki_narodowe /311_parki_narodowe.html Accessed 07/20/2014. 